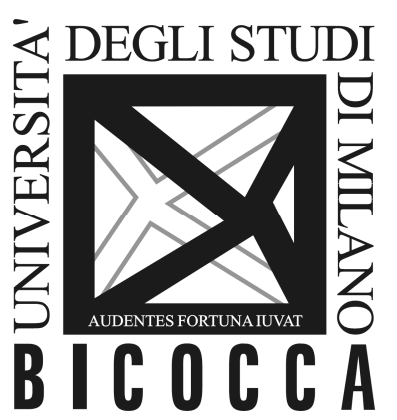

\author{
DEPARTMENT OF ECONOMICS, \\ MANAGEMENT AND STATISTICS \\ UNIVERSITY OF MILAN - BICOCCA
}

DEMS WORKING PAPER SERIES

\title{
Learning by hiring, network centrality and within-firm wage dispersion
}

Ambra Poggi, Piergiovanna Natale

No. 369 - August 2017

Dipartimento di Economia, Metodi Quantitativi e Strategie di Impresa Università degli Studi di Milano - Bicocca

http://dems.unimib.it/ 


\title{
Learning by hiring, network centrality and within-firm wage dispersion
}

\author{
Ambra Poggi \\ (Università degli Studi di Milano-Bicocca, CISEP \\ and Laboratorio Revelli - Collegio Carlo Alberto) \\ Piergiovanna Natale \\ (Università degli Studi di Milano-Bicocca)
}

This version

7 August 2017

In this paper, we highlight knowledge as specific channel through which labour mobility affects conditional within-firm wage dispersion. We present a model in which workers acquire knowledge on the job and firms pursue a policy of learning-by-hiring. The latter generates workers flows that connect directly and indirectly firms in a network. The model predicts that firms central to the network, those with the most heterogeneous workforce in terms of past employers, have the highest wage dispersion. Using 1990-2001 Veneto (a region of Italy) matched employer-employee data, we map workers flows between firms and build the network formed by all the firms. For each firm, we assess its network centrality. In our data conditional within-firm wage dispersion turns out to be increasing in network centrality, confirming the prediction of the model.

JEL Classification: J31, J62, L14

Keywords: Wage dispersion; Labour mobility, Network; Knowledge transfer

\section{Corresponding author}

Piergiovanna Natale

Università degli Studi di Milano-Bicocca

Piazza dell'Ateneo Nuovo 1

20126 Milano

piergiovanna.natale@unimib.it

tel. +390264483095

fax +390264483085 


\section{Introduction}

Firms are heterogeneous in the distribution of the wages they offer. Within the same labour market, we observe variations in average wage and wage dispersion across firms. Such heterogeneity is only partially accounted for by the human capital composition of a firm's workforce. The conditional (on worker's observable characteristics) component of average wage and within-firm wage dispersion has been extensively investigated, empirically as well as theoretically. Market imperfections are called upon to explain it. Search frictions account for wage dispersion across workers, so that otherwise identical workers receive different wages at identical firms (see e.g. Mortensen, 1990; Burdett and Mortensen, 1998). Combing search frictions with human capital accumulation generates heterogeneity in withinfirm wage dispersion (Fu, 2011). Absent worker mobility, within-firm wage dispersion emerges as the equilibrium outcome in presence of moral hazard. This is the case of tournament (Lazear and Rosen, 1981; Lazear, 1989) as well as hierarchical models of production (Williamson, 1967; Calvo and Wellisz, 1979; Qian, 1994).

In this paper, we highlight knowledge as specific channel through which labour mobility affects conditional within-firm wage dispersion and offer new empirical evidence consistent with it.

We present a model in which knowledge is at the same time an essential input of production and a byproduct of production activity. Knowledge as a by-product of production activity is rarely codified. It takes the form of tacit knowledge: information and best-practices workers acquire on the job and can bring to any new job within the firm or any new firm they join. It follows that firms hiring away workers from other firms active in the market can acquire knowledge otherwise not available. This induces firms to pursue a strategy of learning-by-hiring (Parrotta and Pozzoli, 2012; Serafinelli 2016). Furthermore, combing tacit knowledge from a variety of sources, firms can improve their productivity (Villalta-Bufi, 2010). This gives firms an incentive to hire away workers from a wide array of firms active in the market. However, firms are heterogeneous in their ability to produce and to absorb complex knowledge (Cohen and Levinthal, 1990). The more complex is the knowledge it is able to digest, the larger the set of firms from which a firm can hire away workers. Furthermore, firms able to digest complex knowledge are likely to hire away workers from firms that hired away workers from other firms in the past, that is: they hire carriers of knowledge of increasing complexity. The learning-by-hiring policy generates workers flows that connect directly and indirectly firms in a network. Firms able to digest complex knowledge are central to the network. Firm succeed in attracting workers carrying complex knowledge when it matches wage offers by current employers. With training costs increasing in the complexity of knowledge, wage offers by current employers too are increasing in the complexity of knowledge. It 
follows that firms central to the network - those with the most heterogeneous workforce in terms of past employers - have also the highest wage dispersion.

Using employer-employee matched data from a highly industrialized Italian region, we document a positive correlation between conditional within-firm wage dispersion and workforce heterogeneity in terms of past employers. Our data provide us with individual worker's employment history and thus, in principle, with information about a firm's workforce heterogeneity in terms of past employers. To take advantage of the information in our data, we apply network theory. We map workers flows between firms and build the network formed by all the firms. For each firm, we then proceed to assess its network centrality, a measure based on the idea that a firm hiring workers from a large number of firms obtains more knowledge and, thus, is located at a more central position than others. In our data conditional within-firm wage dispersion turns out to be increasing in network centrality. That is, the more heterogeneous is the workforce in terms of their previous employers, the greater is a firm's conditional wage dispersion.

The contribution of our paper to the literature is two-fold. We contribute to the literature on wage dispersion, providing evidence of conditional within-firm wage dispersion in a market at almost full employment and explaining it by means of the role played by workers as carriers of tacit knowledge. We contribute to the literature on knowledge transfer. The latter usually identifies knowledge carriers by means of the wage premium firms pay to attract them (Parrotta and Pozzoli, 2012). We endogenize the wage premium and relate it to a firm's absorptive capacity. We jointly determine workers flows connecting firms in a network and conditional wage dispersion and document in the data a correlation between the position of the firm in the network (that gives information on the amount of knowledge acquired through learning-by-hiring) and within-firm wage dispersion.

The remaining of the paper is organized as follows. In Section 2, we review the literature. In Section 3, we present the model. In Section 4, we introduce the dataset and present the measure of network centrality. In Section 5, we illustrate our empirical strategy and discuss the results. Section 6 concludes.

\section{Literature review}

In this section, we briefly review important literature contributes to within-firm wage dispersion, knowledge spillover and learning-by-hiring. These elements allow us to lay the foundations for our model.

\subsection{Within-firm wage dispersion}

Wage dispersion is an empirical fact. We observe wage dispersion across occupations, sectors and groups. We also observe within firms wage dispersion and, in this paper, we are interested in suggesting a possible explanation for the latter. 
Efficiency wage models and tournament theories provide interesting results concerning the dispersion of earnings within firms. The main idea is that firms choose a distribution of earnings (and, therefore, the level of wage dispersion) in order to elicit desired levels of individual productivity. Efficiency wage models address differences in wages across occupations that involve different monitoring technologies. In firms where the workers' characteristics are not totally observable and where the monitoring of their actions is not perfect, employers have to find well-suited incentives to induce the worker to exercise the optimal amount of effort.

According to Akerlof and Yellen (1990), a worker's effort depends not only on the wage level but also on the degree of wage dispersion within the firm. Using this expression, the authors argue that a compressed wage distribution improves labour relations and stimulates the average worker's effort. Levine (1993) highlights that pay compression, within a firm where teamwork among employees is essential, sustains and stimulates cohesiveness, which increases the firm's total productivity. Milgrom (1988) and Milgrom and Roberts (1990) emphasize that the implementation of some wage equity can reduce the potential tendency of workers to take personal interest decisions, which may not be profitable for the organisation as a whole. In contrast to efficiency wage models, tournament theories point to the benefits of a more dispersed wage structure, deriving from a performance-based pay system (Lazear and Rosen, 1981; Lazear, 1989). Managers should introduce a large spread in the rewards of workers in order to stimulate their effort. In other words, firms should establish a prize structure and award the largest prize to the most productive worker. Lazear (1989) argues, however, that high within-firm wage dispersion could also generate too much competition among workers leading to non-cooperative or sabotage behaviors which may negatively affect firm performance.

Firm hierarchies (defined as the number of managerial and supervisory layers within firms) provide a alternative explanation for wage dispersion within firms. Knowledge-based hierarchy theories assume that wage differences across layers are determined by knowledge differences (Garicano, 2000; Garicano and Rossi-Hansberg, 2006; Caliendo and Rossi-Hansberg, 2012). Incentive-based hierarchy theories (Williamson, 1967; Calvo and Wellisz, 1979; Qian, 1994) imply higher wages for observationally equivalent workers in higher layers because managers receive less monitoring and their effort is more valuable. Both models of knowledge-based and incentive-based hierarchies suggest that the optimal number of hierarchy layers increases with production scale. These models interpret managers as fixed costs that reduce marginal costs by making workers more productive (Friedrich, 2015). Thus, additional managers will decrease average costs if production scale is sufficiently large. Adding hierarchical layers has implications for the wage distribution within firms because higher-level managers receive high 
wages due to their productive effect on a large range of workers. ${ }^{1}$ At the same time, wages decrease for workers at the production level because managers can be considered either problem solvers whose knowledge reduces skill requirements of workers or supervisors whose monitoring substitutes for wage incentives to prevent shirking.

An important source of wage dispersion is on-the-job search. In principle, job mobility is sufficient to generate earning differentials between identical workers working at identical firms (Mortensen, 1990; Burdett and Mortensen, 1998). ${ }^{2}$ The mechanism is simple: unemployed workers are willing to take low paid employment as they can continue to search for better paid work while employed. Combining mechanisms of job mobility with mechanisms of human capital accumulation ${ }^{3}$ allows to offer interesting insights on within firms wage dispersion. For example, Burdett et al. (2011) analyse an equilibrium labour market with on-the-job searches and experience effects. They model workers wage as composed of a worker fixed effect (initial ability), a firm fixed effect (the firm's piece) and experience. They show that the learning-by-doing sorting equilibrium (where over time more experienced workers tend to find and quit for better paid employment) increases equilibrium wage dispersion within and across firms. Learning-by-doing reduces unemployed worker reservation wages (e.g. unemployed workers are willing to accept low wages as work experience is valuable) and increases wage competition across firms for experienced workers. Moreover firms which pay higher piece rates attract and retain a more experienced, and thus more productive, workforce. Fu (2011) combines on-the-job searches and firm funding general training (i.e. ex ante identical firms decide, in addition to their pay rates, whether or not to provide costly training that improves their workers general skill). The model shows that wage dispersion exists because identical workers are paid differently across firms, workers differ in their productivity ex post and there is a positive correlation between pay rate earned and human capital. It offers an explanation for the systematic difference in within-firm wage dispersion across firms and generates correlations between various firm characteristics that are consistent with the data.

Summing up, the literature has elaborated alternative explanations of within-firm wage dispersion. In efficiency wage models and tournament theories, wage dispersion is a choice variable and not the result of market processes. The choice of the optimal number of hierarchy layers allows to consider wage dispersion as endogenously determined. Moreover, knowledge-based hierarchies suggest the importance

\footnotetext{
${ }^{1}$ A similar result can be derived also by the theory of superstars (Rosen, 1981, 1982). In Rosen (1982), we read: “Assigning persons of superior talent to top positions increases productivity by more than the increments of their abilities because greater talent filters through the entire firm by a recursive chain of command technology. These multiplicative effects support enormous rewards for top level management in large organizations" (p. 311).

2 Assuming firm's heterogeneity and worker's heterogeneity help to better fit empirical data (Bontemps et al. , 2000; PostelVinay and Robin, 2002).

${ }^{3}$ Since the pioneering work of Becker (1964) and Mincer (1974), human capital theory has been used to explain the wage growth of workers over the life cycle. According to this theory, wages increase as workers accumulate both firm-specific and general skills. Moreover, human capital theory demonstrates that earnings dispersion is a prerequisite for significant skill investments (Neal and Rosen, 2000).
} 
of knowledge as mechanism inducing within-firm wage dispersion. Combining the importance of knowledge (in terms of human capital accumulation) with mechanisms of job mobility allows explaining within-firm wage dispersion in presence of labour market frictions. However, other explanations may emerge. In this paper, we show that within-firm wage dispersion may also endogenously emerge in absence of labour market frictions when labour mobility and knowledge spillovers are assumed. In particular, we show that within-firm wage dispersion can arise from learning-by-hiring strategies firms pursue when workers are carriers of valuable knowledge.

\subsection{Knowledge spillover and learning-by-hiring strategy}

Knowledge spillovers are at the heart of a number of literature strands. The literature on agglomeration effects posits knowledge spillovers as a main determinant of firms' location choice (Krugman, 1991; Combes and Duranton, 2006). The literature on endogenous growth - started by Romer (1986) identifies knowledge spillovers across firms as a driver of productivity and ultimately economic growth (Jaffe, 1986; Parrotta and Pozzoli, 2012). Knowledge spillovers are the focus also of the literature investigating the effects of FDI on local firms' productivity (Glass and Saggi, 2002; Fosfuri et al., 2001; Javorcik, 2004; Poole, 2013).

Labour mobility has been recognized as a natural candidate to account for knowledge transfer across firms (Arrow, 2012). Knowledge - either tacit or formal - is embodied in workers and thus worker flows across firms are a likely source of knowledge spillovers. However, worker flows across firms are - at least partially - determined by a firm's hiring policy. A sizeable body of literature studies theoretically and empirically the so-called learning-by-hiring strategy, by which firms acquire knowledge through hiring away experts from other firms (Song, Almeida and Wu, 2003).

Whereas a vast empirical literature investigates the impact of labour mobility on innovation activities (Kaiser et al, 2015), evidence of the effect of labour mobility on productivity is limited. Using matched employer-employee data from Danish firms over the period 1980-2005, Parrotta and Pozzoli (2012) estimate the impact of recruiting knowledge carriers - defined as workers holding tertiary education - on the firm's real value added. Their results lend support to the view that learning-by-hiring "enhances productivity at the firm level." (p. 184). Serafinelli (2016) tests the extent by which worker flows affects knowledge transfer from highly productive firms to less productive ones. Using matched employeremployee data from firms located in the North Italy region Veneto over the period 1992-2001, Serafinelli (2016) shows that firms hiring away workers from highly productive firms located nearby experience increases in productivity. This leads the author to conclude that agglomeration effects on productivity are likely to derive from "the propensity of workers to change job within the same local labour market.” (p. 2). Finally, Poole (2013) provides evidence on productivity spillovers from MNEs by examining the impact of the share of workers with past experience at MNEs on the wage of local firm's 
incumbent employees. Using matched employer-employee data from Brazilian firms over the period 1996-2001, Poole (2013) uncovers a positive and sizeable effect of the presence of multinational workers in the workforce on the wage of continuing employees of domestic firms: a $10 \%$ increase in the workforce share of multinational workers leads to increase in the average wage of the same magnitude, an effect of a size comparable to one more month of tenure at the firm.

To the best of our knowledge, very little attention has been devoted in the literature to the consequences of a policy of learning-by-hiring for the distribution of wages at the hiring firm. ${ }^{4}$ A notable exception is Vilalta-Bufi (2010). The aim of Vilalta-Bufi (2010) is to contribute a theory of wage growth and differences in experience premia across industries, for which robust empirical evidence is available. In analogy to Romer (1990), Vilalta.Bufi (2010) models production as increasing in the variety of knowledge a firm commands. Knowledge is embedded in workers and workers with experience at different firms are carriers of different varieties of knowledge. Workers are mobile at a cost and within industries only. Firms belonging to the same industry compete for experienced workers. Competition for experienced workers is shaped by the firm's capacity of absorbing knowledge from workers hired away from other firms. Vilalta-Bufi (2010) posits that firms have full access to the knowledge possessed by workers they trained themselves, whereas they have only partial access to the knowledge possessed by workers trained by others. Firms are homogenous within industries and heterogeneous across industries with respect to their absorptive capacity. Assuming perfect competition on the product and labour markets, Vilalta-Bufi (2010) shows that the wage of experienced workers relative to wage of untrained or young workers is U-shaped in the absorptive capacity of the industry. Increases in absorptive capacity of the industry leads to greater experience premia when absorptive capacity is above a threshold, so that the productivity gains from hiring experienced workers more than compensate the mobility costs firms must cover, thus intensifying competition for experienced workers. Heterogeneity in the absorptive capacity leads to heterogeneity in experience premia across industries, ${ }^{5}$ whereas firms belonging to the same industry exhibit the same within-firm wage dispersion.

We follow Vilalta-Bufi (2010) in modeling production as an increasing function of varieties of knowledge while we depart from it in assuming that firms competing for the same experienced workers differ in their absorptive capacity. This departure is key to account for within-firm wage dispersion across firms otherwise identical.

\section{The model}

\footnotetext{
${ }^{4}$ Consider Parrotta and Pozzoli (2012): knowledge carriers are identified by the condition that "the incomer's wage is greater than the average wage recorded in the recipient firm" (p. 171), thus implying but not testing an association between a policy of learning-by-hiring and within-firm wage dispersion.

${ }^{5}$ The same holds for heterogeneity in labour mobility costs, learning by doing, industry's technological level, substitutability of different varieties of trained workers and number of knowledge varieties in the industry.
} 
In this section we present a simple model in which the optimal hiring policy of heterogeneous firms gives rise to mobility of workers across firms as well as intra-firm wage dispersion. The driving force of the model is the notion of learning-by-hiring. Workers are carriers of complex knowledge developed as a by-product of production activities, and firms are prepared to pay a wage premium to secure their services. However, firms are heterogeneous in their ability to absorb knowledge from transferred personnel. This leads to endogenous flows of workers across firms, linking them in a network. A firm's absorptive capacity determines its position in the network and the latter affects its wage distribution.

Consider an economy populated with $n$ firms. We think of it as a region where firms locate in close proximity so that workers incur no mobility costs. ${ }^{6}$

In each period, there is a pool of potential entrants in the economy. Each entrant $i$ has probability $\pi$ to enter the economy. Probability $\pi$ can be interpreted as capturing the importance of credit constraints or the success rate of innovation activities. If in the economy, firm $i$ produces a good sold on a competitive market at a constant price $p_{i} \cdot{ }^{7}$ In the present model, we think of an entrant as a newly constituted firm. Alternatively, we could consider a firm already active in the economy and engaging in a new project. However, this would complicate the algebra without offering additional hindsight to our model. The important point is that we focus on expanding firms to separate the effects of learning-by-hiring from the consequences of labour turnover on wage distribution.

Upon entering the economy, the entrant incurs a sunk cost $c_{i}$ to set up a production facility of size $C_{i}$. The size of the production facility is assumed to be exogenously given. This simplifying assumption is justified by our focus on the hiring policy of the firm. To start production, firm $i$ hires labour services. The production function of firm $i$ is $Y_{i}=H_{i}^{\alpha} C_{i}^{1-\alpha}$, where $H_{i}$ is a measure of effective units of human capital and $0<\alpha<1$. The firm can hire labour services from the pool of unemployed workers as well as from the pool of workers currently employed at any other firm in the economy. We refer to the former as untrained workers and to the latter as trained workers. Call $\lambda_{i}^{0}$ the amount of untrained labour hired by firm $i$. The amount of trained labour firm $i$ hires away from firm $j$ is $\lambda_{i}^{j}$. We posit $H_{i}$ to be a CES function of the amount of untrained and trained labour hired by firm $i$ :

$$
H_{i}=\left(\left(\lambda_{i}^{0} k_{0}\right)^{\alpha}+\sum_{j=1}^{n}\left(\lambda_{i}^{j} q_{i}^{j} k_{j}\right)^{\alpha}\right)^{\frac{1}{\alpha}} \text {, with } j \neq i
$$

\footnotetext{
${ }^{6}$ Alternatively, we can think of the economy as a technological space, that is: an industry comprising firms that share a production technology so that workers suffer no human capital obsolescence when switching firm.

${ }^{7} \mathrm{We}$ assume that each entrant operates on a different product market.
} 
$k_{0}$ is amount of knowledge possessed by an untrained worker. The amount of knowledge possessed by a trained worker hired away from firm $j$ is $k_{j}$. We assume the amount of knowledge possessed by trained workers to be the same across workers. Following Vilalta-Bufi (2010), workers are heterogeneous in the kind of knowledge they possess. Trained workers are the carriers of the tacit knowledge produced by firms. We can think of it as industry specific knowledge as well as organizational knowledge. ${ }^{8}$ By hiring away workers from firm $j$, firm $i$ acquires its tacit knowledge. In the literature, this phenomenon is referred to as learning-by-hiring. However, firms differ in the complexity of tacit knowledge they produce. Complexity reflects the diversity of know-how and working practices ${ }^{9}$ embedded in the firm tacit knowledge and it affects the transferability of such knowledge. Cohen and Levinthal (1990, p. 140) remark that "Although it is difficult to specify a priori all the relevant characteristics of knowledge affecting the ease of learning, they would include the complexity of the knowledge to be assimilated...". Firms can be ordered by the complexity of the tacit knowledge they produce and is embedded in their employees, with firm 1 producing less complex knowledge than any other firm.

We model the impact of complexity on knowledge transferability by assuming that firm $i$ can absorb only a fraction $0 \leq q_{i}^{j}<1$ of knowledge $k_{j}$. We posit $q_{i}^{j}$ to be declining in the complexity of knowledge $k_{j}$, with $q_{i}^{1}$ being the largest and $q_{i}^{j}=0$ for some value of $j$. Note that absorptive capacity is firm-specific. Cohen and Levinthal (1990, p. 129) argue that an "organization needs prior related knowledge to assimilate and use new knowledge". Entrepreneurs entering the economy may differ in their past experience and related prior knowledge. ${ }^{10}$ This affects firm $i$ 's absorptive capacity of each firm j's tacit knowledge. We model heterogeneity in absorptive capacity among firms as follows: higher absorptive capacity allows firms to absorb knowledge from a larger set of firms. Take two entrants in the economy, firm $l$ and $h$. Firm $h$ has higher absorptive capacity than $l$ as long as:

$$
\begin{aligned}
& q_{l}^{j}=q_{h}^{j}>0, \forall j=1, \ldots . g ; \\
& q_{l}^{j}=0 \text { and } q_{h}^{j}>0, \forall j=g+1, \ldots . g+k ; \\
& q_{h}^{j} \geq 0, \forall j=g+k+1, \ldots . n .{ }^{11}
\end{aligned}
$$

\footnotetext{
${ }^{8}$ Note that untrained and trained workers can be either skilled or unskilled. Because we are interested in the transmission of tacit knowledge across firms through labour mobility, we presently abstract from skill heterogeneity. Likewise, we abstract from any other characteristic of workers that may affect wages. This is consistent with our empirical strategy by which we study the determinants of within-firm wage dispersion conditional on workers' and firms' observable characteristics.

${ }^{9}$ Sutton (2012) refers to them as a firm's capability.

${ }^{10}$ Entrants may also differ in the R\&D investment they undertake prior to enter the economy, which may affect their absorptive capacity. In the current model, we take such investment as exogenous because we focus on the firm's hiring policies.

${ }^{11}$ Alternatively, we could model heterogeneity in absorptive capacity by assuming $q_{h}^{j}>q_{l}^{j}, \forall j=1, \ldots . g$. This would increase the complexity of the algebra without qualitatively affecting the results.
} 
Untrained workers have the least complex knowledge. The set of untrained workers comprises workers that never had an occupation and long-term unemployed, as we posit that tacit knowledge depreciates over time. We set $q_{i}^{0}=1$ across all $i$.

Substituting (1) into the production function, we obtain:

$$
Y_{i}=\left\{\left[\left(\lambda_{i}^{0} k_{0}\right)^{\alpha}+\sum_{j=1}^{n}\left(\lambda_{i}^{j} q_{i}^{j} k_{j}\right)^{\alpha}\right]^{\frac{1}{\alpha}}\right\}^{\alpha} C_{i}^{1-\alpha}
$$

The output of firm $i$ is increasing in the transferable amount and variety of knowledge possessed by the workers hired away from other firms. Different types of knowledge exhibit complementarity. However, because of the additive nature of the function $H_{i}$, production can take place also by employing a subset of the varieties of knowledge available in the economy.

Firm $i$ demands labour services to maximize its profit. The supply of untrained workers is infinitely elastic at wage $r_{0}$. To attract workers employed at other firms, firm $i$ must offer a wage at least equal to the wage the current employer $j$ is ready to pay in order to retain the trained worker. The maximum wage firm $j$ is willing to pay to retain a trained worker is the replacement cost. To substitute for a trained worker, firm $j$ has two options: it can either recruit an untrained worker or hire away a trained worker from any other firm in the economy. In both cases, firm $j$ must incur a training cost that we assume to be increasing in the complexity of the firm's tacit knowledge. Call $r_{j} \geq r_{0}$ the wage firm $j$ pays to retain its trained workers. It follows that firm $i$ succeeds in hiring away workers from firm $j$ if and only if it is prepared to pay at least $r_{j}$. If the number of workers employed by firm $j$ is large with respect to the demand of labour services of variety $j$ by the pool of entrants, firm $i$ needs to pay no more than $r_{j}$. Recalling that firm $i$ sells its output on a competitive market at constant price $p_{i}$, we can write the profit maximization problem of firm $i$ as follows:

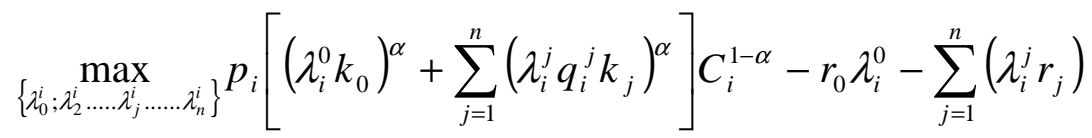

The first order conditions for the above problem are: ${ }^{12}$

$$
\left\{\begin{array}{l}
p_{i} \alpha\left(\lambda_{i}^{0} k_{0}\right)^{\alpha-1} k_{0} C_{i}^{1-\alpha}-r_{0}=0 \\
p_{i} \alpha\left(\lambda_{i}^{1} q_{i}^{1} k_{1}\right)^{\alpha-1} q_{i}^{1} k_{1} C_{i}^{1-\alpha}-r_{1}=0 \\
\cdot . \\
p_{i} \alpha\left(\lambda_{i}^{n} q_{i}^{n} k_{n}\right)^{\alpha-1} q_{i}^{n} k_{n} C_{i}^{1-\alpha}-r_{n}=0
\end{array}\right.
$$

The solutions to the above system of equations are the labour service demands by firm $i$ :

\footnotetext{
${ }^{12}$ The selected functional forms ensure that second order conditions are satisfied.
} 


$$
\begin{gathered}
\hat{\lambda}_{i}^{0}=\left(\frac{\alpha p_{i} C_{i}^{1-\alpha} k_{0}^{\alpha}}{r_{0}}\right)^{\frac{1}{1-\alpha}} \\
\hat{\lambda}_{i}^{j}=\left(\frac{\alpha p_{i} C_{i}^{1-\alpha}\left(q_{i}^{j} k_{j}\right)^{\alpha}}{r_{j}}\right)^{\frac{1}{1-\alpha}}, j=1,2 \ldots . n
\end{gathered}
$$

The hiring strategy of firm $i$ is driven by its absorptive capacity. Other things equal, the larger $q_{i}^{j}$, the greater the amount of trained labour services of type $j$ hired by firm $i$. We refer to it as the intensive margin of firm $i$ 's hiring. Furthermore, there is an extensive margin of firm $i$ 's hiring. Firm $i$ hires away workers from firm $j$ only if $q_{i}^{j}>0$. Other things equal, the larger the set of $q_{i}^{j}>0$, the greater the number of firms from which firm $i$ hires away workers and thus the greater the variety of labour services firm $i$ employs. ${ }^{13}$

Heterogeneity in absorptive capacity among firms has implications on composition of the workforce and the distribution of wages within firms.

Consider two arbitrary selected potential entrants, $h$ and $l$. Posit $p_{h}=p_{l}$ and $C_{h}=C_{l}$. The only source of heterogeneity is in the absorptive capacity. Let us assume $h$ to have higher absorptive capacity than $l$ :

$$
\begin{gathered}
\mathbf{q}_{\mathbf{h}}=\left[q_{h}^{1}=q^{1} ; \ldots \ldots . q_{h}^{g}=q^{g} ; q_{h}^{g+1}>0 ; . . q_{h}^{g+k}>0, q_{h}^{g+k+1}=0 \ldots . . q_{h}^{n}=0\right] \\
\mathbf{q}_{\mathbf{h}}=\left[q_{l}^{1}=q^{1} ; \ldots \ldots . q_{l}^{g}=q^{g} ; q_{l}^{g+1}=0 ; \ldots . . q_{h}^{n}=0\right]
\end{gathered}
$$

Firm $h$ and $l$ are able to absorb the same fraction of the tacit knowledge produced by firm $j=1, \ldots ., g$. However, firm $h$ only can absorb the tacit knowledge produced by firm $j=g+1, \ldots, g+k$.

It follows that firm $h$ and $l$ hire the same number of workers from the pool of unemployed and from a subset of firms active in the economy, namely from firms indexed from 1 to $g$. However, firm $h$ hires away workers from firms producing tacit knowledge of greater complexity than firm $g$, that is those firms indexed from $g+1$ to $g+k$. Note that the entrant may hire away workers from firms that in the past followed the very same hiring strategy. Suppose firm $i$ hires away workers from firm $j$, which in turn hired away workers from firm $v$. By this strategy, firm $i$ is employing labour services of variety $j$ which incorporates tacit knowledge of type $v$. We model stratification of tacit knowledge by means of complexity. The larger the number of firms from which a firm hired away workers, the greater the complexity of the knowledge possessed by its workers and the higher the wage the latter command. We conclude that only firms with high absorptive capacity hire away workers from firms that hired from other firms in the past.

\footnotetext{
${ }^{13}$ We have argued that $q_{i}^{j}=0$ for some value of $j$. When this is the case, firm $i$ hires away workers from all firms up to $j-1$. Were the demand for labour services expressed by means of a discrete variable, we could have $q_{i}^{j}>0$ and $\hat{\lambda}_{i}^{j}=0$.
} 
The total number of firms which an entrant has direct or indirect ties with - that is: whose tacit knowledge an entrant acquires by means its hiring policy - is increasing in its absorptive capacity. The distribution of absorptive capacity across firms determines the endogenous formation of a network, in which firms are linked by workers flows. We refer to a firm with a large number of direct and indirect ties - in terms of workers flows - as central to the network. High absorptive-capacity firms hire workers away from a larger number of firms than low absorptive-capacity ones; moreover they hire workers that the latter would find it unprofitable to hire because of the high wage they command. Thus, high absorptive-capacity firms call on a larger variety of (more complex) knowledge than low absorptivecapacity ones. To put it differently, more central firms may be able to call on more of the resources (knowledge) of the network as a whole (Wasserman and Faust, 1994).

Our model predicts that a firm's centrality positively impacts on within-firm wage dispersion.

It is to easy to see that the range of the wage distribution is higher for firm $h$ than firm $l$ : $r_{g+k}-r_{0}>r_{g}-r_{0}$. Furthermore, the variance of the wages paid by firm $h$ exceeds the variance of the wages paid by firm $l$ whenever the following condition is satisfied:

$$
\left\{\begin{array}{l}
\frac{1}{\sum_{j=1}^{g} \hat{\lambda}^{j} \sum_{j=1}^{g+k} \hat{\lambda}_{j}} \sum_{i=1}^{k} \hat{\lambda}_{g+i} \hat{\lambda}_{0}\left(r_{g+i}-r_{0}\right)\left[\left(r_{g+i}-r_{0}\right)-\left(r_{h}+r_{l}\right)\right]+ \\
\frac{1}{\sum_{j=1}^{g} \hat{\lambda}^{j} \sum_{j=1}^{g+k} \hat{\lambda}_{j}} \sum_{i=1}^{k} \hat{\lambda}_{g+i} \sum_{j=1}^{g} \hat{\lambda}_{j}\left(r_{g+i}-r_{j}\right)\left[\left(r_{g+i}-r_{j}\right)-\left(r_{h}+r_{l}\right)\right]
\end{array}\right\}>0
$$

where $r_{h}\left[r_{l}\right]$ is the average wage paid by firm $h[l]$.

A sufficient condition for (9) to hold is:

$$
\left\{\begin{array}{l}
\frac{1}{\sum_{j=1}^{g} \hat{\lambda}^{j} \sum_{j=1}^{g+k} \hat{\lambda}_{j}} \hat{\lambda}_{g} \hat{\lambda}_{0}\left(r_{g}-r_{0}\right)\left[\left(r_{g}-r_{j}\right)-\left(r_{h}+r_{l}\right)\right]+ \\
\frac{1}{\sum_{j=1}^{g} \hat{\lambda}^{j} \sum_{j=1}^{g+k} \hat{\lambda}_{j}} \hat{\lambda}_{g} \sum_{j=1}^{g} \hat{\lambda}_{j}\left(r_{g}-r_{j}\right)\left[\left(r_{g}-r_{j}\right)-\left(r_{h}+r_{l}\right)\right]
\end{array}\right\}>0
$$

Furthermore, as $k$ increases condition (9) is likelier to hold: the greater a firm's absorptive capacity, the greater its wage dispersion around the mean.

Heterogeneity in the complexity of tacit knowledge positively affects within-firm wage dispersion. Assume all firms produce tacit knowledge of the same degree of complexity. When this is the case, they pay the same wage to retain their employees. As a consequence, hiring firms offer the same wage to workers transferring from any firm in the economy. The distribution of wages within firms entails only two values, $r_{0}$ and $r_{j}$. On the contrary, heterogeneity in tacit knowledge complexity entails a dispersion 
in the wage offers employers make to retain their workers; given heterogeneity in absorptive capacity, the latter in turn entails wage dispersion within firms pursuing learning-by-hiring. In the next sections we discuss how we test the predictions of our model.

\section{Data, measures and descriptive statistics}

\subsection{Data}

Our empirical analysis is based upon mapping individual reallocations in Veneto, a region of Italy. Veneto is a highly industrialized Nuts-2 Italian region that ranks among the most developed and densely populated regions in Europe. During the period under analysis, the Veneto labour market was characterized by a positive rate of job creation in both manufacturing and services, and by almost frictional unemployment, accompanied by high labour mobility, with worker turnover comparable to Anglo-Saxon countries. The economic activities are widespread over the entire territory. But, there is also evidence of spatial agglomeration pivoted around a plurality of small and medium urban centres and industrial districts (Brusco, 1986; Becattini et al., 1990; Tattara and Anastasia, 2003) indicating that a large number of firms are indeed interconnected. For all these reasons, Veneto represents an interesting area to perform our analysis.

We use Veneto Worker Histories (VWH), a longitudinal linked employer-employee dataset developed at the Department of Economics of the University of Venice Ca' Foscari on the basis of administrative records of the Italian Social Security Institute. This longitudinal dataset covers the universe of worker histories in Veneto in the private sector for more than twenty years, up to 2001. The main advantage of this dataset is that it permits recovery of virtually all individual transitions between firms; moreover, the administrative nature of the data ensures that the obtained network is indeed a reliable representation of the true fabric of labour mobility (Gianelle, 2014).

In particular, VWH includes register-based information that allows building a history of the working life of each employee who has been hired for at least one day by an establishment based in Veneto, during the period of observation, regardless of the worker's place of residence. On the employee side, the VWH includes total earnings during the calendar year for each job, the number of days worked during the year, the worker's gender, age, region (country) of birth, occupation and seniority with the firm. On the employer side, the VWH includes the sector, the dates of "birth" and closure of the firm (if applicable) and the firm's location.

Changes in the legal ownership may represent an issue. In principle, the firm identifier changes each time the legal ownership of the firm changes, even if the underlying operations do not cease, or changes in the nature of the activity are not appreciable. Many such situations have been recognized: if more than $50 \%$ of the employees are taken over by a new employer, the business is said to be continuous and the 
old employer is assigned the identifier of the new employer. The remainder of such situations could represent a problem for our analysis (leading to overestimation of job mobility) and have been ruled out restricting our data set to firms that operates throughout the entire period of study (1990-2001). ${ }^{14}$ A second restriction applies to firm size. It would not be very meaningful to observe reallocations and to calculate wage dispersion for firms with very few employees. Hence, for each year, we restrict our data set to firms with at least 50 employee observations. ${ }^{15}$ Our sample includes individuals aged between 15 and 65 years employed in 1396 medium and large sized firms in industries and services sectors. Over the period 1995-2001, we have a sample of just under 2,000,000 individuals (see Table 1). On average $34 \%$ of our workers are female, $18 \%$ are between the ages of 15 and 25, 71\% are between the ages of 26 and 49 , and $11 \%$ are aged 50 or above. About $4 \%$ of the employees are immigrants. Average tenure is about 6 years and $56 \%$ of workers have 10 or more years of experience. The mean daily wage is 62 Euros. ${ }^{16}$

[Insert Table 1about here]

\subsection{A measure of the firm's position in the network}

In section 3, we refer to a firm with a large number of ties as central to the network, where ties represent workers hired away from other firms. A very simple, but often very effective measure of a firm's centrality is its degree (that is, the number of ties that a firm has), which is based on the idea that a firm hiring workers from a larger number of firms obtains more knowledge, and thus is located at a more central position than others. In contrast, an actor with a low degree, who appears to be less visible in the knowledge flows, is peripheral in the network.

Degree centrality measures only take into account the immediate ties that a firm has rather than indirect ties to all others as our model does. In our model, by hiring away a worker form firms that hired away workers from other firms (connected firms), a firm obtains more complex knowledge than by hiring a worker away from disconnected firms (that is, firms that never hired workers away from other firms). We need a measure able to capture it. A possible solution can be found using closeness centrality, a measure that emphasizes the distance of each firm to all others in the network (Freeman, 1978; Opsahl et al., 2010; Wasserman and Faust, 1994). ${ }^{17}$ In facts, closeness centrality takes both, direct connections and indirect connections, into consideration. Formally, the closeness centrality of firm $j$ is defined as the inverse of the sum of geodesic distances (shortest-path) from firm $j$ to all other firms in the network:

\footnotetext{
${ }^{14}$ The length of the period of study is an issue. We select a period as long as possible taking into account that longer periods lead to smaller balanced firm panels. A period of eleven years seems to be a good compromise. We performed a sensitivity analysis using shorter periods and our results are robust. Related tables are available upon request from the authors.

${ }^{15}$ There are some degrees of arbitrariness in this choice. A sensitivity analysis has been performed, see Section 5 .

${ }^{16} \mathrm{We}$ use daily gross wages as our wage variable and we calculate full-time equivalent real wages. No restrictions are imposed on the duration of job spells, nor on the type of occupation. To ensure that a few extreme observations do not skew the results, we delete some outliers: employees with very high or low/zero wages.

${ }^{17}$ Closeness centrality is one of the most widely used centrality measures; however, the choice of the type of centrality measure involves some degree of arbitrariness; we select the one that in our opinion is better able to describe knowledge transfers through labour worker mobility.
} 


$$
C_{j}=\frac{1}{\Sigma_{j=k} d(j, k)}
$$

where $d(j ; k)$ is the geodesic distance (shortest-path) between firms $j$ and $k$. For example, if firm $j$ hires workers away from firm $k$, e $d(j ; k)$ is equal to one; moreover, if firm $j$ hires workers away from firm $k$ and the latter firm hired workers away from firm $q$, then $d(j ; q)$ is equal to two. In other words, firm $j$ obtains "complex knowledge" from firm $k$. This "complex knowledge" is composed by the direct knowledge obtained by firm $k$ plus the indirect knowledge obtained by firm $q{ }^{18}$

As the distance between firms in disconnected components of a network is infinite, the closeness centrality measure cannot be applied to networks with disconnected components (Opsahl et al., 2010; Wasserman and Faust, 1994). And, this is exactly our case: about $3.41 \%$ of firms are isolated (that is, they never hired workers away from other firms). Therefore, we use the modified measure of closeness centrality proposed by Opsahl (2010). He suggests a possible solution which allows the measure to be applied to networks with disconnected components and at the same time maintain the original idea behind the measure. Since the intra-component closeness scores are not infinite for all the firms in the network and the limit of a number divided by infinity is zero, we measure closeness centrality as the sum of inversed distances to all other firms instead of the inverse of the sum of distances to all other firms:

$$
\text { Network }_{j}=\sum_{j \neq k} \frac{1}{d(j \cdot k)}
$$

We calculate the normalized scores of equation (12) that are bound between 0 and 1 . It is 0 if a firm is isolated, and 1 if a firm is directly connected to all others. Weights based on the number of workers hired away from other firms (that indicate the strength of the ties) are used as appropriate.

Finally, we calculate the modified measure of closeness centrality over five-year periods. In our view, "five years" represent a reasonable period for observing job-to-job movements. ${ }^{19}$ Descriptive statistics about the modified measure of closeness centrality are shown in Table 2. Firm closeness centrality is on average about 0.095 . The maximum is below one (it does not achieve 0.155 ) indicating that no one firm is connected to all others. In particular, as said above, about $3.41 \%$ of the firms are isolated (register a value equal to zero). Closeness centrality slightly increases over time showing on average an increase in the degree of connection between firms.

\section{[Insert Table 2 about here]}

\footnotetext{
${ }^{18}$ Our network is a directed network (Knoke and Burt, 1983): since knowledge is embedded in workers and diffuses when workers move to other firms, we only consider the firm opportunities of knowledge acquisition, that are the number of ties (hired workers) received by a firm (indegree). We do not consider the number of ties sent by a firm (outdegree). Indeed, a worker separation represents a loss in term of human capital and will affect pay dispersion at firm level. However, we are interested in studying the relationship between knowledge spillovers due to hiring workers away from other firms and wage dispersion. Thus, we focus only on indegree.

${ }^{19}$ Three year periods have also been tested; results (available upon request) are robust.
} 
Figure 1 investigates the relationship between firm size and closeness centrality. We split the firms into four equal size groups using the quartiles of closeness centrality (firms in group 1 have the lowest centrality, while firms in group 4 have the highest centrality). For each group, we display the distribution of firm size using a box plot. In a box plot the central rectangle spans the first quartile to the third quartile (the interquartile range of wage distribution), the segment inside the rectangle shows the median and "whiskers" above and below the box show the locations of the minimum and maximum (unless there are outliers).

\section{[Insert Figure 1 about here]}

Figure 1 shows clear evidence of a positive association between firm size and closeness centrality. This is not a surprising finding since larger firms are indeed able to hire more workers. However, closeness centrality is a more complex concept than "number of workers hired by the firm". It focuses on workers hired away from other firms and knowledge flows among firms. Therefore, even if firm size and closeness centrality are positively correlated, closeness centrality does not vary systematically depending on firm size.

\section{Empirical strategy}

\subsection{Methodology}

In this section we empirically test the main prediction of our model: we examine the impact of a firm's position in the labour mobility network on within-firm wage dispersion. Two types of within-firm wage dispersion indicators can be found in the literature: unconditional indicators, by which wage dispersion is measured across heterogeneous workers, and conditional indicators, where wage dispersion is measured across workers with similar observable characteristics. We use the latter type of indicator.

To calculate our conditional wage dispersion indicator, we follow the Winter-Ebmer and Zweimüller (1999) methodology which rests upon a two-step estimation procedure. In the first step, we estimate by OLS the following wage equation for each firm and each year separately:

$$
\ln w_{i j}=a_{0}+x_{i j} a_{1}+\varepsilon_{i j}
$$

where $w_{i j}$ is the gross wage of worker $i$ in firm $j, x_{i j}$ is the vector of individual characteristics including age, age squared, sex, tenure, experience dummies, immigration dummy and occupation dummy (blue collar), and $\varepsilon_{i j}$ is the error term. Note that using covariates as experience dummies ${ }^{20}$ is particularly important to separate between mechanisms of human capital accumulation that make workers more productive (and, then, better paid) from the effects of potential knowledge spillovers due to job-to-job mobility.

\footnotetext{
${ }^{20}$ We use the following dummies: experience is 0-2 years; experience is 2-5 years; experience is 5-10 years; experience is 10 or more years. To construct these dummies we use the 1975-2001 Veneto Worker Histories.
} 
The standard deviations of the residuals of these regressions run firm by firm and year, $\sigma_{j t}$, are then used as a conditional measure of wage dispersion in the second step, which consists in estimating the following firm-level equation:

$$
\sigma_{j t}=\beta_{0}+\text { network } \beta_{1}+x_{j t} \beta_{3}+z_{j t} \beta_{4}+v_{j}+\varepsilon_{j t}
$$

where network is the modified measure of closeness centrality (see Section 4 for details); $\sigma_{j t}$ is the conditional wage dispersion indicator, in level; $x_{j t}$ contains aggregated characteristics of workers in firm $j$ at time $t$ (the share of the workforce that is younger than 25 and older than 50 years, respectively; the share of the workforce with 0-2 year experience and with 2-5 year experience, respectively; the share of women; the share of blue-collar workers; the share of immigrants); $z_{j t}$ includes firm characteristics, i.e. the sectoral affiliation, firm size (and firm size squared), area dummies; $v_{j}$ is firm fixed effect and $\varepsilon_{j t}$ is the error term. Table 1 presents the average conditional within-firm wage dispersion. ${ }^{21}$ By construction, it varies not only between firms but also over time within a given firm. For all firm/year observations, the average conditional dispersion is equal to 0.20 .

Finally, one problem to control for is the potential simultaneity between the modified measure of closeness centrality and wage dispersion. We address this issue by estimating equation (14) using the average measure of closeness centrality over the previous 5 years, instead than the current measure.

\subsection{Estimates}

We present multivariate analysis estimates by regressing closeness centrality on dispersion of the wage levels. First, we use simple OLS to examine differences between firms. In a second step, taking into account unobserved heterogeneity across firms, we estimate fixed effect panel regressions. Finally, we perform some robustness checks.

The OLS regression (Table 3, columns 2 and 3) shows a positive relation between closeness centrality and wage dispersion across firms. In other words, firms with better positions in the networks have larger wage dispersion. However, there could be differences across firms that are not captured by the control variables and affect the position in the network and wage dispersion simultaneously. If there are, biased and inconsistent parameter estimates could result. The firm fixed effects estimation (Table 3, columns 4 and 5) confirms the existence of a positive relation between closeness centrality and wage dispersion across firms. This result confirms the prediction of our model.

\section{[Insert Table 3 about here]}

Many of the other control variables take statistically significant coefficients of the expected sign (Table 3, Columns 4 and 5). The share of white collars is associated with increasing within-firm wage

\footnotetext{
${ }^{21}$ Daily wages are in $\log$ and the average log wage is equal to 4.05 .
} 
dispersion. The shares of the workforce with limited work experiences are also associated with increasing within-firm wage dispersion. In this context, these variables give information on the production technology used by the firms indicating that some input combinations lead to more wage dispersion than others. The percentage of older workers is also positively correlated with wage dispersion. High percentages of part-time employees are associated with reduced wage dispersion. On the other hand, the share of immigrants does not play a role.

\subsection{Robustness checks}

We perform some robustness checks.

First, we test whether our decision to consider only firms with 50 workers or more can affect the results. It is not the case: our results are robust with respect to different subsamples of the data. Similar positive and significant relationships between closeness centrality and wage dispersion emerge when we extend our sample to all firms with 20 workers or more and when we restrict our sample to all firms with 70 workers or more. $^{22}$

Second, we investigate whether the positive correlation between within-firm conditional wage dispersion and network centrality is due to turnover rather than to the role played by workers as carries of tacit knowledge. Turnover may affect unobservable characteristics of the workforce and thus conditional wage dispersion within firms. We regress conditional within-firm wage dispersion on 5-year closeness centrality, 5-year turnover and a term interacting these two. Results are reported in Table 4. The positive relation between closeness centrality and conditional within-firm wage dispersion is robust: knowledge spillovers within firms due to job-to-job movers matters even when we add explicitly controls for labour turnover. Labour turnover does not seem to play a role: the estimated coefficient is zero. Furthermore, we do not observe a statistical significant interaction between labour turnover and network centrality.

[Insert Table 4 about here]

\section{Conclusions}

Wage dispersion within firms has attracted much attention in the literature. Worker's and firm's observable characteristics only partially account for it. Search frictions and moral hazard are usually invoked to explain within-firm wage dispersion conditional on worker's and firm's observable characteristics. In this paper, we argue that within-firm conditional wage dispersion can be the outcome of firms pursuing a policy of learning-by-hiring. Workers are carriers of tacit knowledge. Firms gain access to such knowledge by hiring away workers from other firms active in the market. As long as workers from different firms are carries of imperfectly substitutable tacit knowledge, a firm pursuing a

\footnotetext{
${ }^{22}$ Results are available upon request.
} 
policy of learning-by-hiring is willing to pay higher wages to attract workers that increase heterogeneity in its workforce.

We put the above prediction to the test of data. The main challenge in doing so is to find an appropriate measure of heterogeneity in tacit knowledge. We overcome it by applying network theory to extract information from a data set comprising the employment histories of about 2 million individuals.

Using matched employee-employer data from Veneto region, we map workers flows between firms and build the network formed by all the firms. The notion of closeness centrality provides us with the required measure of heterogeneity in the workforce tacit knowledge. We indeed document a positive correlation between within-firm conditional wage dispersion and closeness centrality and. Thus, our data point in the direction of a positive correlation between within-firm conditional wage dispersion and heterogeneity in the tacit knowledge the firm acquires through a learning-by-hiring policy. Our results are robust to a number of tests. 


\section{References}

Akerlof, G.A. \& Yellen, J.L. 1990, "The Fair Wage-Effort Hypothesis and Unemployment", Quarterly Journal of Economics, vol. 105, no. 2, pp. 255-283.

Arrow, K. J. 2012, In Landstrom H., Lohrke F. T.,eds (Eds.), Economic welfare and the allocation of resources for invention Elgar Research Collection. International Library of Entrepreneurship, vol. 23. Cheltenham, U.K. and Northampton, Mass.: Elgar.

Becattini G., Pyke F. and Sengenberger W. 1990, "Industrial Districts and Inter-Firm Cooperation in Italy", IILS, Geneva

Becker, G. 1964, Human Capital, 2nd edition, New York: Columbia University Press

Bontemps, C., J.M. Robin, and G. J. Van den Berg 2000, "Equilibrium Search with Continuous Productivity Dispersion: Theory and Nonparametric Estimation", International Economic Review, $41(2), 305-58$.

Brusco S. 1986, "Small Firms and Industrial Districts: The Experience of Italy", in Keeble D. and Wever E. (Eds) New Firms and Regional Development in Europe, Croom Helm, London.

Burdett, K. \& Mortensen, D.T. 1998, "Wage Differentials, Employer Size, and Unemployment", International Economic Review, vol. 39, no. 2, pp. 257-273.

Burdett, K., Carrillo-Tudela, C. \& Coles, M.G. 2011, "Human Capital Accumulation and Labor Market Equilibrium", International Economic Review, vol. 52, no. 3, pp. 657-677.

Caliendo, L. \& Rossi-Hansberg, E. 2012, "The Impact of Trade on Organization and Productivity", Quarterly Journal of Economics, vol. 127, no. 3, pp. 1393-1467.

Calvo, G.A. \& Wellisz, S. 1979, "Hierarchy, Ability, and Income Distribution", Journal of Political Economy, vol. 87, no. 5, pp. 991-1010.

Cohen, W.M. \& Levinthal, D.A. 1990, "Absorptive Capacity: A New Perspective on Learning and Innovation", Administrative Science Quarterly, vol. 35, no. 1, pp. 128-152.

Combes, P. \& Duranton, G. 2006, "Labour Pooling, Labour Poaching, and Spatial Clustering", Regional Science and Urban Economics, vol. 36, no. 1, pp. 1-28.

Fosfuri, A., Motta, M. \& Ronde, T. 2001, "Foreign Direct Investment and Spillovers through Workers' Mobility", Journal of International Economics, vol. 53, no. 1, pp. 205-222.

Freeman, L.C. 1978, "Centrality in social networks: Conceptual clarification”, Social Networks vol. 1, pp. 215-239.

Friedrich, B. 2015, “Trade Shocks, Firm Hierarchies and Wage Inequality", Department of Economics and Business Economics, Aarhus University, Economics Working Papers 2015-26.

Fu, C. 2011, "Training, Search and Wage Dispersion", Review of Economic Dynamics, vol. 14, no. 4, pp. 650-666. 
Garicano, L. 2000, "Hierarchies and the Organization of Knowledge in Production", Journal of Political Economy, vol. 108, no. 5, pp. 874-904.

Garicano, L. \& Rossi-Hansberg, E. 2006, "Organization and Inequality in a Knowledge Economy", Quarterly Journal of Economics, vol. 121, no. 4, pp. 1383-1435.

Gianelle C. 2014, "Discovering the regional small world of labour mobility: Evidence from linked employer-employee data", Regional Studies, vol. 48, no. 7, 1263-1278.

Glass, A.J. \& Saggi, K. 2002, "Multinational Firms and Technology Transfer", Scandinavian Journal of Economics, vol. 104, no. 4, pp. 495-513.

Jaffe, A.B. 1986, "Technological Opportunity and Spillovers of R\&D: Evidence from Firms' Patents, Profits, and Market Value", American Economic Review, vol. 76, no. 5, pp. 984-1001.

Javorcik, B.S. 2004, "Does Foreign Direct Investment Increase the Productivity of Domestic Firms? In Search of Spillovers through Backward Linkages", American Economic Review, vol. 94, no. 3, pp. 605-627.

Kaiser, U., Kongsted, H.C. \& Ronde, T. 2015, "Does the Mobility of R\&D Labor Increase Innovation?", Journal of Economic Behavior and Organization, vol. 110, pp. 91-105.

Knoke, D. \& Burt, R.S. 1983, "Prominence", In: Burt, R.S., Minor, M.J. (Eds), Applied Network Analysis. Beverly Hills, Sage Publications, California, pp. 195-222.

Krugman, P. 1991, Geography and trade. Gaston Eyskens Lecture Series Cambridge, Mass. and London: MIT Press; Louvain, Belgium: Louvain University Press.

Lazear, E.P. \& Rosen, S. 1981, "Rank-Order Tournaments as Optimum Labor Contracts", Journal of Political Economy, vol. 89, no. 5, pp. 841-864.

Lazear, E.P. 1989, "Pay Equality and Industrial Politics", Journal of Political Economy, vol. 97, no. 3, pp. 561-580.

Levine, D.I. 1993, "Fairness, Markets, and Ability to Pay: Evidence from Compensation Executives", American Economic Review, vol. 83, no. 5, pp. 1241-1259.

Milgrom, P.R. 1988, "Employment Contracts, Influence Activities, and Efficient Organization Design", Journal of Political Economy, vol. 96, no. 1, pp. 42-60.

Milgrom, P. \& Roberts, J. 1990, "The Efficiency of Equity in Organizational Decision Processes", American Economic Review, vol. 80, no. 2, pp. 154-159.

Mincer, J. 1974, Schooling, Experience and Earnings, New York: Columbia University Press for National Bureau of Economic Research.

Mortensen, D.T. 1990, Equilibrium Wage Distributions: A Synthesis, Contributions to Economic Analysis, vol. 192 Amsterdam; Oxford and Tokyo: North-Holland; distributed in the U.S. and Canada by Elsevier Science, New York. 
Neal, D. \& Rosen, S. 2000, Theories of the Distribution of Earnings, Handbooks in Economics, vol. 16. Amsterdam; New York and Oxford: Elsevier Science, North-Holland.

Opsahl, T., Agneessens, F. \& Skvoretz, J. 2010, "Node centrality in weighted networks: Generalizing degree and shortest paths", Social Networks, vol. 32, pp. 245-251.

Parrotta, P. \& Pozzoli, D. 2012, "The Effect of Learning by Hiring on Productivity", RAND Journal of Economics, vol. 43, no. 1, pp. 167-185.

Poole, J.P. 2013, "Knowledge Transfers from Multinational to Domestic Firms: Evidence from Worker Mobility", Review of Economics and Statistics, vol. 95, no. 2, pp. 393-406.

Postel-Vinay, F. \& Robin, J. 2002, "Equilibrium Wage Dispersion with Worker and Employer Heterogeneity", Econometrica, vol. 70, no. 6, pp. 2295-2350.

Qian, Y. 1994, "Incentives and Loss of Control in an Optimal Hierarchy", Review of Economic Studies, vol. 61, no. 3, pp. 527-544.

Romer, P.M. 1986, "Increasing Returns and Long-run Growth", Journal of Political Economy, vol. 94, no. 5, pp. 1002-1037.

Romer, P.M. 1990, "Endogenous Technological Change", Journal of Political Economy, vol. 98, no. 5, pp. S71-102.

Rosen, S. 1981, "The Economics of Superstars", American Economic Review, vol. 71, no. 5, pp. 845858.

Rosen, S. 1982, "Authority, Control, and the Distribution of Earnings", Bell Journal of Economics, vol. 13, no. 2, pp. 311-323.

Serafinelli, M. 2016, “Good' Firms, Worker Flows and Local Productivity", unpublished manuscript. file://C:/Users/natale/Downloads/serafinelli_worker_flows_v2.pdf

Song, J., Almeida, P. \& Wu, G. 2003, "Learning-by-Hiring: When is mobility more likely to facilitate inter-firm knowledge transfer?," Management Science, vol. 49, no. 4, pp. 351-365.

Sutton, J. 2012, Competing in capabilities: The globalization process, Clarendon Lectures in Economics, Oxford and New York: Oxford University Press.

Vilalta-Bufi, M. 2010, "On the Industry Experience Premium and Labor Mobility", Labour Economics, vol. 17 , no. 3 , pp. 547-555.

Tattara G. and Anastasia B. 2003, "How was that the Veneto region became so rich? Time and causes of a recent success”, MPRA Paper No. 18458.

Wasserman, S. \& Faust, K. 1994, Social Network Analysis: Methods and Applications, Cambridge University Press.

Williamson, O.E. 1967, "Hierarchical control and optimum firm size", Journal of Political Economy, vol. 75, pp. 123-138. 
Winter-Ebmer, R. \& Zweimuller, J. 1999, "Intra-Firm Wage Dispersion and Firm Performance", Kyklos, vol. 52, no. 4, pp. 555-572. 
Figure 1. Firm size by closeness centrality groups (group $1=$ the lowest centrality; group $4=$ the highest centrality)

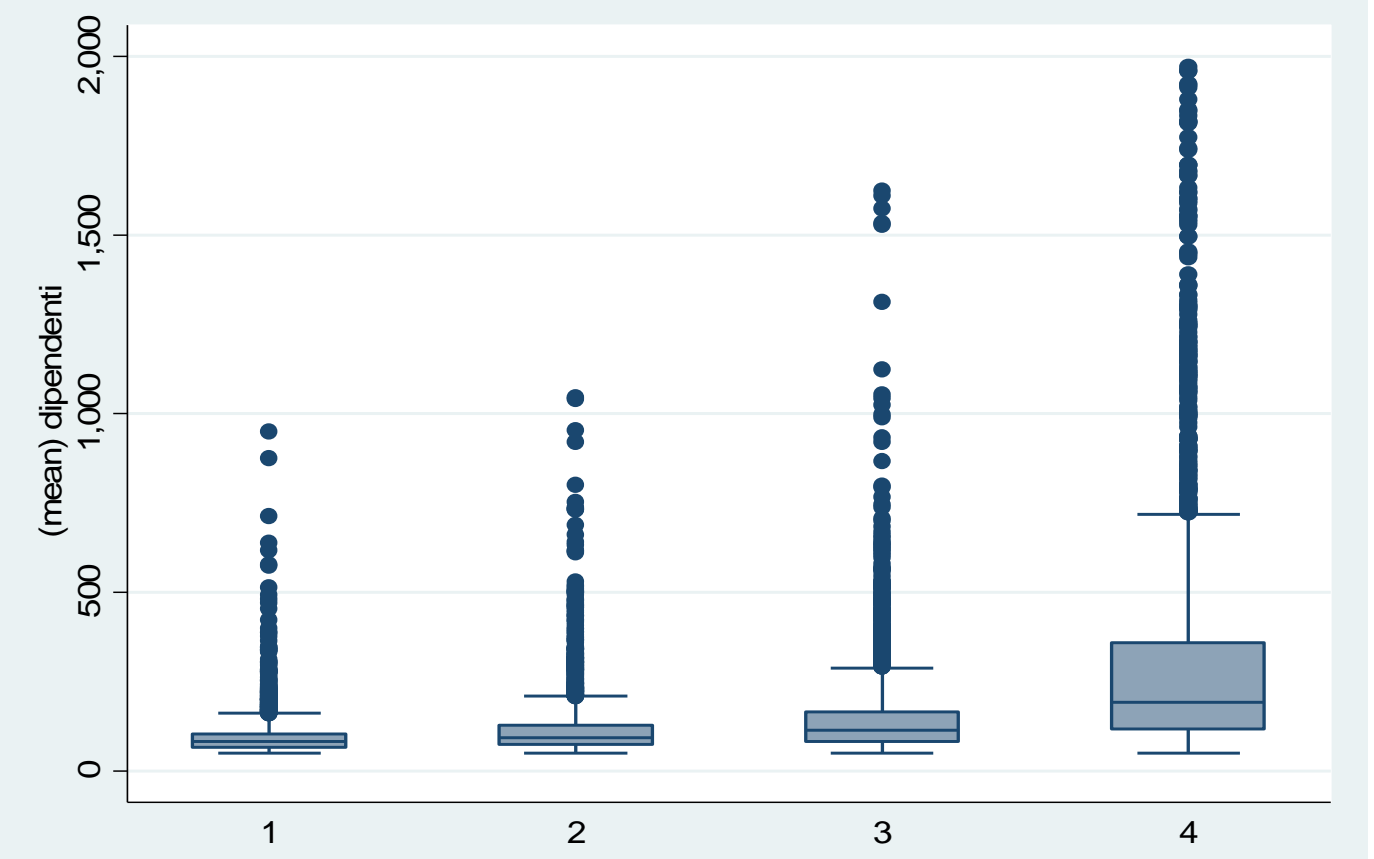


Table 1. Sample descriptive statistics: period 1995-2001

\begin{tabular}{|l|r|}
\hline Descriptive statistics (\%) & \multicolumn{1}{|c|}{ All } \\
\hline Females & 34.47 \\
Age is 15-25 & 17.69 \\
Age is 26-49 & 71.21 \\
Age is 50+ & 11.10 \\
Apprentice & 2.65 \\
Blue collars & 64.00 \\
White collars & 33.35 \\
Part time & 8.40 \\
Average tenure (years) & 6.11 \\
Experience is (0-2) years & 10.59 \\
Experience is [2-5) years & 13.03 \\
Experience is [5-10) years & 19.86 \\
Experience is 10+ years & 56.52 \\
Immigrants & 4.08 \\
Firm size: 50-99 & 21.49 \\
Firm size: 100-199 & 23.53 \\
Firm size:<199 & 54.98 \\
Industry & 71.87 \\
Area is Belluno & 5.72 \\
Area is Padova & 14.76 \\
Area is Rovigo & 2.01 \\
Area is Treviso & 18.96 \\
Area is Venice & 15.89 \\
Area is Vicenza & 22.97 \\
Area is Verona & 19.69 \\
\hline Average daily wage (log) & 4.05 \\
Average unconditional within-firm wage dispersion (sd) & 0.39 \\
Average conditional within-firm wage dispersion (condineq) \\
\hline No. Obs & 0.20 \\
\hline No. Firms & 1396 \\
\hline
\end{tabular}

Table 2. Modified measure of closeness centrality

\begin{tabular}{|c|c|c|c|c|}
\hline \multicolumn{5}{|c|}{$\begin{array}{l}\text { Average No. of reallocations by firm (over the period 1990-2000): } \\
18.41\end{array}$} \\
\hline Network & Mean & Std. Dev. & Min & Max \\
\hline Period 1990-1994 & 0.085 & 0.023 & 0 & 0.137 \\
\hline Period 1991-1995 & 0.090 & 0.024 & 0 & 0.144 \\
\hline Period 1992-1996 & 0.091 & 0.024 & 0 & 0.142 \\
\hline Period 1993-1997 & 0.094 & 0.023 & 0 & 0.143 \\
\hline Period 1994-1998 & 0.098 & 0.021 & 0 & 0.149 \\
\hline Period 1995-1999 & 0.101 & 0.020 & 0 & 0.150 \\
\hline Period 1996-2000 & 0.102 & 0.021 & 0 & 0.151 \\
\hline
\end{tabular}

Percentage of isolated firms: $3.41 \%$. 
Table 3. Estimation results

\begin{tabular}{|c|c|c|c|c|c|c|}
\hline \multicolumn{7}{|l|}{ Dependent variable: conditional within-firm wage dispersion } \\
\hline \multirow[t]{2}{*}{ Covariates } & \multicolumn{3}{|c|}{ OLS } & \multicolumn{3}{|c|}{ Fixed Effects } \\
\hline & Coef & & S.E. & Coef & & S.E. \\
\hline Network centrality (average over the previous 5 years) & 0.2740 & $* *$ & 0.0418 & 0.0550 & $* *$ & 0.0200 \\
\hline Females $(\%)$ & 0.0279 & $* *$ & 0.0045 & 0.0170 & & 0.0091 \\
\hline Workers with [0-2) years experience (\%) & 0.0875 & $* *$ & 0.0191 & 0.0341 & $* *$ & 0.0090 \\
\hline Workers with $[2-5)$ years experience $(\%)$ & 0.1049 & $* *$ & 0.0176 & 0.0326 & $* *$ & 0.0089 \\
\hline Workers under $25(\%)$ & 0.1059 & $* *$ & 0.0164 & 0.0445 & $* *$ & 0.0088 \\
\hline Workers over $50(\%)$ & 0.0108 & & 0.0176 & 0.0351 & $* *$ & 0.0108 \\
\hline Apprentice $(\%)$ & $0.0127^{-}$ & & 0.0186 & 0.0186 & & 0.0109 \\
\hline White Collars (\%) & 0.0646 & $* *$ & 0.0059 & 0.0541 & $* *$ & 0.0065 \\
\hline Part time $(\%)$ & $\begin{array}{r}- \\
-\end{array}$ & & 0.0117 & $\begin{array}{r}- \\
0.0499\end{array}$ & $* *$ & 0.0079 \\
\hline Immigrant (\%) & 0.0236 & & 0.0164 & 0.0079 & & 0.0110 \\
\hline No. Employees & $2 \mathrm{E}-05$ & $* *$ & 0.0000 & 0.0001 & $* *$ & 0.0000 \\
\hline No. Employees - squared & $-5 E-09$ & $* *$ & 0.0000 & $-8 \mathrm{E}-09$ & $* *$ & 0.0000 \\
\hline Industry & 0.0263 & $* *$ & 0.0033 & --- & & --- \\
\hline Area dummies & yes & & yes & --- & & --- \\
\hline Year dummies & yes & & yes & yes & & yes \\
\hline Constant & 0.1062 & $* *$ & 0.0073 & 0.1469 & $* *$ & 0.0043 \\
\hline sigma_ $v$ & & & & 0.0393 & & \\
\hline sigma_E & & & & 0.0255 & & \\
\hline rho & & & & 0.7038 & & \\
\hline R-sq: within & & & & 0.1308 & & \\
\hline R-sq: between & & & & 0.1461 & & \\
\hline R-sq: overall & 0.2290 & & & 0.1417 & & \\
\hline No. Obs & 9772 & & & 9772 & & \\
\hline No. Firms & 1396 & & & 1396 & & \\
\hline
\end{tabular}

Note: $(* *)$ statistical significant at $1 \%$ level; $(*)$ statistical significant at $5 \%$ level 
Table 4. Estimation results considering labour turnover: fixed effects model

\begin{tabular}{|c|c|c|c|c|c|c|}
\hline Dependent variable: conditional within-firm wage dispersion & Coef & & S.E. & Coef & & S.E. \\
\hline Network centrality (average over the previuos 5 years) & 0.0668 & $* *$ & 0.0222 & 0.0742 & $* *$ & 0.0235 \\
\hline Turnover & $-1.6 \mathrm{E}-05$ & & 0.0000 & 4.9E-05 & & 0.0001 \\
\hline Interaction: network centrality*turnover & no & & no & -0.0006 & & 0.0007 \\
\hline Covariates & yes & & yes & yes & & yes \\
\hline Constant & 0.1469 & ** & 0.0044 & 0.1458 & $* *$ & 0.0045 \\
\hline sigma_ $\boldsymbol{V}$ & 0.0390 & & & 0.0390 & & \\
\hline sigma_E & 0.0254 & & & 0.0254 & & \\
\hline rho & 0.7015 & & & 0.7018 & & \\
\hline R-sq: within & 0.1314 & & & 0.1315 & & \\
\hline R-sq: between & 0.1437 & & & 0.143 & & \\
\hline R-sq: overall & 0.1383 & & & 0.1378 & & \\
\hline No. Obs & 9772 & & & 9772 & & \\
\hline No. Firms & 1396 & & & 1396 & & \\
\hline
\end{tabular}

Note: $(* *)$ statistical significant at $1 \%$ level; $(*)$ statistical significant at $5 \%$ level 